\title{
The Implications of Unsustainable Agricultural Land Resources Exploitation in the Widikum-Menka Highlands, North West Cameroon
}

\author{
Tassah Ivo Tawe ${ }^{1,}$, Akenji Victorine $\mathrm{Neh}^{2}$ \\ ${ }^{1}$ Department of Geography, University of Yaoundé 1, Yaoundé, Cameroon \\ ${ }^{2}$ Department of Geology and Environmental Science, University of Buea, Buea, Cameroon \\ Email address: \\ tasswise $a$ yahoo.co.nz (T. I. Tawe), akenjivictorine $a$ yahoo.com (A. V. Neh) \\ ${ }^{*}$ Corresponding author
}

\section{To cite this article:}

Tassah Ivo Tawe, Akenji Victorine Neh. The Implications of Unsustainable Agricultural Land Resources Exploitation in the Widikum-Menka Highlands, North West Cameroon. American Journal of Environmental and Resource Economics. Vol. 1, No. 1, 2018, pp. 34-45.

doi: $10.11648 /$ j.ijls.20180101.15

Received: October 19, 2017; Accepted: November 8, 2017; Published: January 2, 2018

\begin{abstract}
Natural Resources are of great importance to mankind and land in particular is of greater importance in terms of agriculture and rural development. Land as an agricultural resource is of valuable significance especially to developing economies that largely depend on it for the production of both food and cash crops. Land and the benefits that can be derived from it have been taken for granted and undervalued by civilizations in both past and present, despite warnings of the need for careful land stewardship in the world. Today, the pressure on land has reached such a critical point that serious doubts have been raised on the capacity of the land to meet the demands of a human population rapidly increasing to 9 billion. Land constitutes the fundamental livelihood asset of the rural poor in most parts of Cameroon and the North West Region in particular. The exploitation of this resource for food and poverty alleviation in a highland environment like the WidikumMenka area in the face of a rapid population growth calls for some urgent concerns, as the land degradation problem which has been manifested through frequent landslide, accelerated erosion, loss of habitat, decreasing agricultural yields and ecological disturbance are rife. This paper therefore aims at examining the implications of the unsustainable land resources exploitation in the Widikum-Menka highland with the view of bringing order in the organization of human activities in this diverse agroecological zone which can yield maximum productivity while guaranteeing the stability of the environment. To attain this objective, both the descriptive and analytical methods of investigation were used and several field surveys, interviews and focused group discussions were carried out. This paper also uses the DFPSIR and DPIR framework to give explicit attention to the environmental as well as human impacts of pressures caused by the more fundamental driving forces. The results obtained shows that land resource degradation among other resources remains the major threat to rural livelihoods over the area. The rate of decrease in the parameters within the two decades is rated high according to some agro-technicians. Despite this warning, the study disclosed that, land degradation may persist for the rest of the millennium since there exist no blue prints for sustainable agriculture and land management for the sub region. As such; there is therefore need for the government and NGOs to mainstream Climate-Smart Agriculture (CSA) as a farming practice in this region.
\end{abstract}

Keywords: Land Resources, Unsustainable Exploitation, Implications, Prospects, Widikum-Menka Highlands, Cameroon

\section{Introduction}

Land is a vital factor of production for all development endeavors and a critical determinant of wellbeing, livelihood and economic stability. The importance of natural resources, especially land to agriculture and rural development is well recognized. Unlike in advanced and industrialized countries, the function of land as a production resource is still very crucial as the economic fortune of most developing countries, however, revolves largely around the exploitation and use of land resources especially in the primary industry such as, agriculture (Titilola and Jeje, 2008). Land as an agricultural 
resource is of valuable significance especially to developing economies that largely depend on it for the production of both food and cash crops for subsistence and for the local as well as international market. Globally, 2.6 billion people depend directly on agriculture, $52 \%$ of the land used for agriculture is moderately or severely affected by soil degradation, 4-6 million ha of cultivated land are lost annually due to anthropogenic soil degradation, cropland in developing countries decreased from 0.43 ha to 0.26 ha per capita in the period from the 1960s to the 1990s. Furthermore, for cropland production, the total cropland worldwide is 1.5 billion ha, cropland affected by soil degradation is $38 \%, 55 \%$ of the gross value of food is produced under rain fed agriculture. Cropland in dry rain fed areas is used primarily by smallholder farmers to cultivate field and cash crops. For rangelands, the total rangeland surface worldwide is 3.4 billion ha while the rangeland affected by soil degradation is $73 \%$ (Gabathuler, Liniger, Christine, Markus (2009)).

Land and the benefits that can be derived from it have been taken for granted and undervalued by civilizations both past and present, despite warnings of the need for careful land stewardship found throughout ancient writings. Today, the pressure on land has reached such a critical point that serious doubts have been raised on the capacity of land to meet the demands of a human population rapidly increasing to 9 billion (ELD Initiative, 2013). There is a potentially devastating downward spiral of overexploitation and degradation, enhanced by the negative impacts of climate change - leading in turn to reduce availability of natural resources and declining productivity: this jeopardises food security and increases poverty (Liniger, Mekdaschi, Hauert, and Gurtner, 2011).

On a global scale, crop production challenges like expansion of cultivated fields and the diminishing of natural vegetation cover, insufficient amounts of organic materials and nutrients, burning of organic materials (harvest residue, bush fires), soil erosion (wind and water) can be noticed. Furthermore, it has been noticed that the livestock population has increased dramatically in rangeland areas in recent years, thus, resulting to the Tragedy of the Commons. Rangeland problems such as overgrazing, burning and increase in undesirable plants, insufficient soil organic carbon, soil degradation (erosion, compaction, crusting), free grazing, no clear land use rights have been noticed especially in rangelands in the developing world (Gabathuler, Liniger, Christine, Markus (2009). These challenges have all resulted to climate change, rural poverty and food and nutrition insecurity, which are the three urgent and interlinked problems facing the global community today (McCarthy and Brubaker, 2014).

There is available evidence pointing to the fact that sound and sustainable environmental management is essential for maintaining the natural resource base upon which nations depend for their continued agricultural and rural development (Titilola and Jeje, 2008). Sustainable agricultural land management practices (SLM) is the antidote that has the power to increase average productivity, reduce seasonal fluctuations in yields, and ensure diversification and improved incomes. For example, adoption of practices, such as agro-forestry species, minimum tillage and residue management, and soil and water conservation structures, can lead to climate change adaptation and mitigation benefits, as well increased and more stable yields, thereby increasing food security (McCarthy and Brubaker, 2014). Furthermore, sustainable land management practices harbour great potential for preservation and enhancement of ecosystem services.

Land constitutes the fundamental livelihood asset of the rural poor in most parts of Cameroon and the North West Region in particular. The exploitation of this resource for food and poverty alleviation in a highland environment like the Widikum-Menka area in the face of a rapid population growth calls for some urgent concerns, as the land degradation problem which has been manifested through frequent landslide, accelerated erosion, loss of habitat, decreasing agricultural yields and ecological disturbance are rife (Lambi, 2001; Lambi et al., 2008; Tassah \& Lambi, 2014). The Widikum-Menka montane ecological zone which forms parts of the Bamenda Highlands of the North West Region of Cameroon is home to a peasant population who depend entirely on agriculture to give life a meaning (Tassah, 2013). Entirely a rural area with a weak economy and the high rate of illiteracy, the exploitation of the land in this area for food and socio-economic livelihood does not provide any meaningful consideration for rehabilitation. In the circumstances therefore, there is a drastic reduction in the potentials of the natural resource base from its productive capacity to sustain the rapidly growing population.

\section{The Problem}

The highlands of the Widikum-Menka area represent a diverse agro-ecological zone in which the inhabitants depend absolutely on the land for their basic livelihood and socioeconomic stability. The unsustainable exploitation of this resource by the peasant farmers for agriculture and other basic needs has left large expanses of the landscape stripped of its vegetation. This has accelerated the rapid rates of soil erosion loss, decrease in the soil fertility parameters, loss of habitats and ecological imbalances.

The increasing urge for food security within the background of a rapid population growth in this montane landscape has resulted in the inefficient placement of different human functions on space. The mountainous landscape has introduced some microclimatic variability within the different agro-ecological niches. This affects agricultural production which is the fundamental livelihood asset of the peasant population. According to Becha (2013), communal tendencies in land resource exploitation characterize the way of life of this peasant population. The exploitation of this resource as a common pull property has further resulted in the degradation problem which affect crop yield. 
The desire to grasp more land for agriculture even beyond their resource frontier through the most unsustainable methods is further worsening the situation. This is manifested as the agricultural output of most families now suffices just for home consumption and their inability to rely on the degraded landscape for income generation. Falling standards of living and declining livelihood security has aggravated the rate of out migration while in some cases has provoked the occurrence of conflicts between individuals, families, and villages (resource users), with far reaching consequences. Thus, poverty is further intensifying its grip on this rural population.

This paper is therefore aimed at examining the implications of the unsustainable land resources exploitation in the Widikum-Menka highland with the view of bringing order in the organization of human activities in this diverse agro-ecological zone which can yield maximum productivity while guaranteeing the stability of the environment.

\section{Research Locale and Methods}

\subsection{Research Locale}

The Widikum-Menka montane ecological zone is situated between latitude $9^{\circ} 30$ and $9^{\circ} 50$ East of the Greenwich Meridian and longitude $6^{\circ} 10$ and $5^{\circ} 50$ North of the Equator. The area is enclaved and composed of four clans which are Widikum, Menka, Bussam and the Ambelle. The area lies between two climatic types which are the humid equatorial rainforest climate in the Mamfe basin and the dry savannah climate in the northern parts of the Bamenda Highlands. The area is made up of subsistent peasant farmers who eke out a living mainly from the land.

\subsection{Methods}

This study is based on a field survey that was carried out in the Widikum-Menka montane area in the months of October and November 2016. It adopts both the descriptive and analytical methods of investigation and further complimented by review from published and unpublished sources, interviews and focused group discussions. With regards to field observation, vital primary data were generated by the researcher intuition based on longevity in the area. Under this, the researcher embarked on observing the following; the various human activities and their intensities in the area. Evaluating the potentials of the different ecological niches as well as assessing the environmental peculiarities. Investigating evidence of land degradation and taking note of their spatial intensities. Also, interviews and focused group discussions were major sources of data. In total, thirty five farmers were interviewed on the methods of farming practices adopted, agricultural productivity in terms of outputs, land management methods adopted amongst others took the central stage of the interviews.

In an attempt to justify land degradation, a chemical test on soil samples collected from this region was performed.
This was to ascertain the magnitude of change in soil quality over a period of thirty one years (1985 and 2016). Two sample sites were selected on the basis of their representation for the entire study area. Two soil samples were collected from two different plots, one in the highland savannah zone of the Menka area and the other in the forested humid zone in the Widikum area. These two soil samples were analyzed in a soil sample laboratory in IRAD Ekona (South West Region). The results obtained were compared with similar soil samples carried out by the Agronomic Research Center (IRAD) Ekona in 1985 (obtained from MIDENO, Bamenda). The data obtained were analyzed and presented in the form of tables, figures and maps.

\subsection{Conceptual Framework}

The Driving Force-Pressure-State-Human ImpactResponse (DFPSIR) framework is a concept by Holden based on the Pressure-State-Response framework (OECD, 1993) and from the Driving Force-Pressure-Impact-Response (DPIR) framework used by the European Environmental Agency, and UNEP. It gives explicit attention to the environmental as well as human impacts of pressures caused by the more fundamental driving forces.

The components of the DFPSIR framework are as follows:

a. Driving Forces are the underlying factors in form of population growth, technological characteristics and changes, institutional (including political, market, cultural, social) structures and changes. Land laws and land markets are typical institutional factors that affect land resources through the various ways they impact on land management. There are typically nested interactions among these driving forces. Glaring examples within the Widikum-Menka montane landscape are weak institutional arrangements, absence of law enforcement on land resources amidst the growing population.

b. Pressures are the activities that follow from the driving forces and that have direct impacts on the environment. Such pressures within the study area include; Increased food demand and demand for land for agricultural production (forest clearing for extensive agriculture, burning and removal of biomass, inadequate fallow periods, use of erosive crops and cultivation systems, inadequate or no investment in soil and water conservation, overgrazing, mono cropping, and the depletion of open access resources). These Pressures emerge from the incentive structures created by the driving forces.

c. The State of the Environment can be captured by assessing the stock of natural resources, the changes in these stocks or various indicators of environmental quality like, erosion levels, nutrient stocks or flows, soil acidity or salinity, pollution levels, changes in areas or quantities of carbon, loss of species, or loss of habitats. Global warming due to GHG emissions causes changes in air and water temperatures, severity of storms, floods, and droughts. The state of the environment within the Widikum-Menka Highlands has been poised by the caprices of the driving 
forces and pressures on the land. This is evident on the landscape through Erosion, Nutrient depletion, Compaction, Acidification, Pollution, Salinization, Loss of agricultural land. Vegetation (Loss of biomass (carbon emissions), Loss of biodiversity, Habitat fragmentation and destruction amongst others).

d. Human Impacts of the changes in the environment are measured through a range of indicators, like poverty status, food security or other measures of vulnerability, access to land and other resources, tenure security, market access, access to shelter and other basic human needs, access to safety nets, and the degree of empowerment or political influence. At aggregate level, these are related to the Millennium Development Goals.

e. Responses include responses at local, national and international levels. They can address the Driving Forces, the Pressures, the Environment or Human Well-being. The time perspective may also vary and can be short-term or very long-term.

Examples include Local responses: (Local collective action, New technology adoption and, adaptation; State responses) Improvement of laws and regulations, Decentralization of power, Allocation of government resources for action, Development of plans and strategies, Removal of policy failures, Correction of market failures, Provision of safety nets for poor and vulnerable groups, Investment in research and education, Dissemination of information and coordination; International responses: Coordinate global action., Mobilize funds for action where needed, Technical support. These responses are not evident or even non existence within the study area.

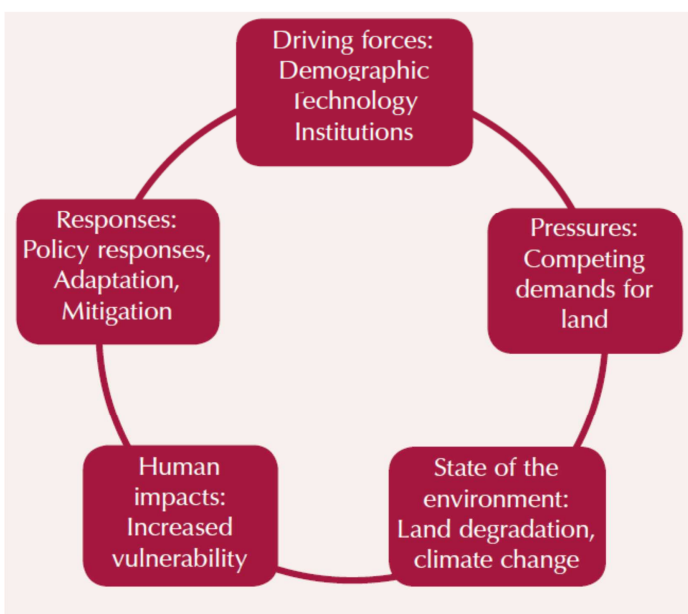

Source: United Nations Habitat (2010).

Figure 1. DFPSIR framework in the Widikum-Menka Sub-Division.

\section{Research Results}

\subsection{Land Resource Potentials and Assets}

The land resource potentials and their assets in the area were observed to be erratic and whose fixed margins were difficult to delimit. However, with the use of criteria such as altitude, climate, nature of vegetation, and farming types, it became convenient to divide the area into two major zones; the lowland forest zone and the highland savannah zone. In this light, it became easier to segregate and evaluate the land resource potentials in each of the zones. Field observation reveals that, in each of the broad ecological zones, small-scale disparities in the occurrence of land resource potentials were common, mostly under the control of slopes, soil characteristics, and the impact of existing stressors (natural or anthropogenic).

Table 1. Resource potentials and uses to man in the various zones of the Widikum-Menka Highlands.

\begin{tabular}{|c|c|c|c|}
\hline Zone & $\begin{array}{l}\text { Natural } \\
\text { Characteristics }\end{array}$ & Resource Potential & Uses to man \\
\hline \multirow{4}{*}{$\begin{array}{l}\text { Zone I: } \\
\text { Lowl and } \\
\text { Forest Zone }\end{array}$} & \multirow{4}{*}{$\begin{array}{l}\text { Less than } 1000 \mathrm{~m} \\
\text { above sea level }\end{array}$} & $\begin{array}{l}\text { Patches of luxuriant natural forest with important timber species such as } \\
\text { Iroko and Mahogany } \\
\text { Plant species are of high medicinal value such as "Ambama" } \\
\text { Extensive lowland }\end{array}$ & $\begin{array}{l}\text {-Timber exploitation, Fuel wood, } \\
\text { Conservation (Community forest ) } \\
\text {-Traditional medicine } \\
\text {-Crop cultivation, Animal rearing }\end{array}$ \\
\hline & & $\begin{array}{l}\text { wildlife resources: (Deer, monkeys, leopard, porcupine (Atherurus } \\
\text { Africanus), pangolin (Manis Temminchkii), bush cats (Leptailurus Serval), } \\
\text { rat mole (Heterocephalus Global), squirrels, birds and snakes }\end{array}$ & $\begin{array}{l}\text { Poaching for subsistence and commercial } \\
\text { purposes }\end{array}$ \\
\hline & & $\begin{array}{l}\text { Fluvial resources such as streams and rivers are common such as the River } \\
\text { Emom, River Tanjoh and the famous River Momo. }\end{array}$ & $\begin{array}{l}\text {-fishing (commercial and subsistence), } \\
\text { water for agriculture, sand mining } \\
\text { (domestic and commercial purposes }\end{array}$ \\
\hline & & Humid lateritic soil: high depth and moderate fertility & Food crop and cash crop cultivation \\
\hline \multirow{4}{*}{$\begin{array}{l}\text { Zone II: } \\
\text { Highl and } \\
\text { Savannah }\end{array}$} & \multirow{4}{*}{$\begin{array}{l}\text { Greater than } \\
1000 \mathrm{~m} \text { above sea } \\
\text { level, }\end{array}$} & $\begin{array}{l}\text {-Savanna Vegetation } \\
\text {-High lands and Rangeland }\end{array}$ & $\begin{array}{l}\text { Animal grazing during the rainy season } \\
\text { Patches of vegetation and high savannah } \\
\text { grasslands are a good source of tourism. }\end{array}$ \\
\hline & & $\begin{array}{l}\text { Wildlife and birds: cane rats, rock rabbits, rat mole and squirrels. Endemic } \\
\text { bird species like hawks, parrots, banner mans, dove among others. }\end{array}$ & $\begin{array}{l}\text { Poaching for subsistence and commercial } \\
\text { purposes }\end{array}$ \\
\hline & & $\begin{array}{l}\text { Plant species: Presence of endemic tree species such as "iyvoum", } \\
\text { "ambama" and mahogany }\end{array}$ & $\begin{array}{l}\text { Soil nourishment ("iyvoum"), Timber } \\
\text { exploitation, Craft works ( "ambama"), } \\
\text { Traditional medicine }\end{array}$ \\
\hline & & $\begin{array}{l}\text { Soil: stony-black earth (cultivation of cocoyams, superficial deposits, thin } \\
\text { soil on the slopes (short cycle crops such as maize, beans and groundnut) }\end{array}$ & Food and cash crop cultivation \\
\hline
\end{tabular}

Source: Field survey (2016). 


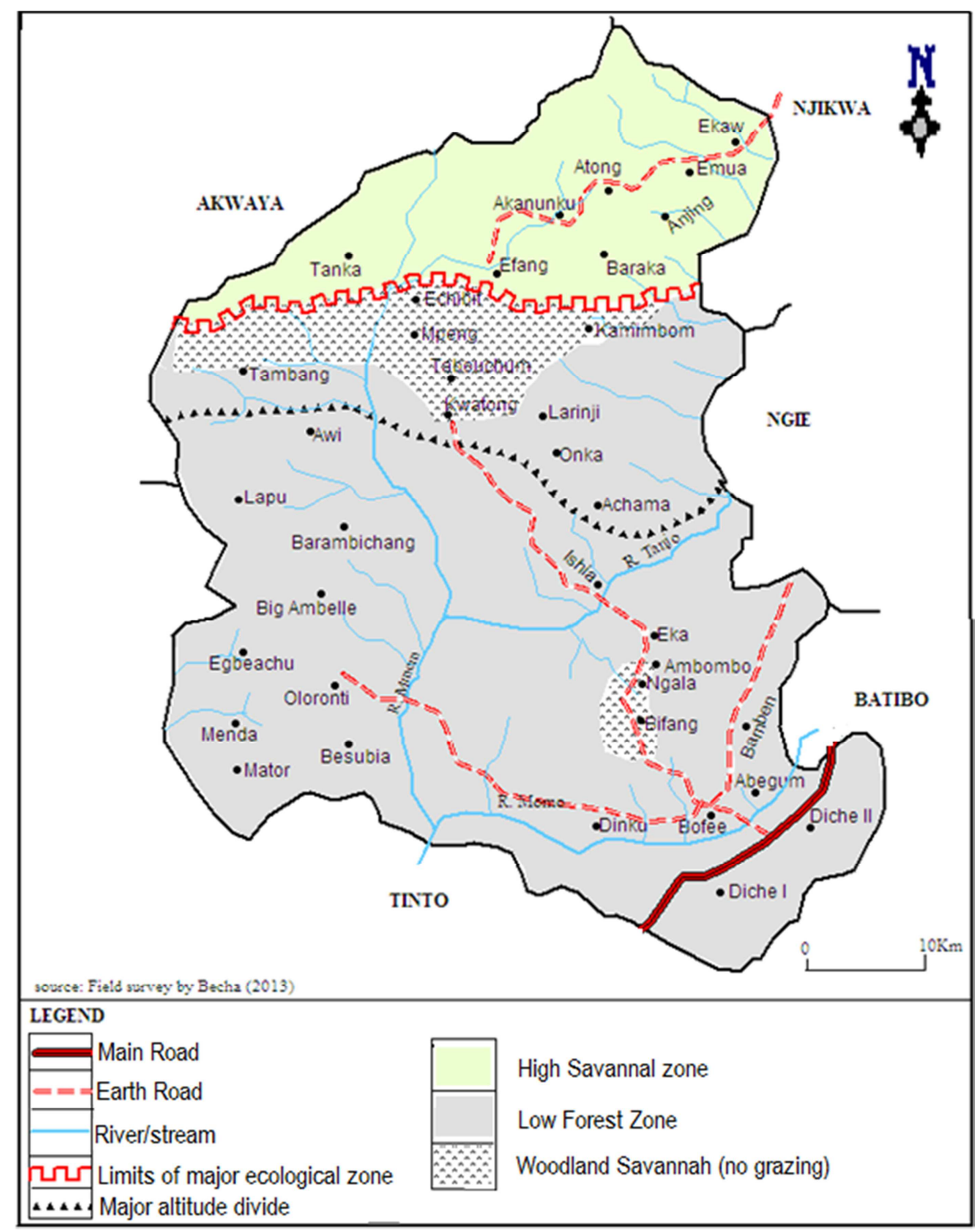

Figure 2. The major ecological zones in the Widikum-Menka Highlands.

\subsection{Land as a Resource}

Land is the most vital asset of the people of WidikumMenka Highland especially as it is massively used for agricultural purposes. Land in the context of this study is narrowed down to the soil which is the most vital productive asset to the rural poor. The soil is at the centre of life in the area suggesting why agriculture is still looked upon as the fulfillment of destiny to many (Becha, 2013). The soils within this highland zone are diverse as portrayed in their chemical and physical attributes (Table 6). The development and patterns of occurrence of the soil types in the area was observed to have been influenced by factors like; the parent rock which is predominantly granitic, the nature of relief, climate, biomass density, and most importantly the type and intensity of human land-use practices on the landscape. The soils in this area are predominantly lateritic which range from medium to low quality across the study area. The high annual rainfall of $2500 \mathrm{~mm}$ and hilly landscape further facilitates the leaching and washing away of soil nutrients which diminishes their potential for crop production.

\subsection{Agricultural Land Uses}

The various agricultural land uses within the study area is a reflection of the different agro ecological zones. In this light, livestock rearing is concentrated within the mountainous rangelands in the Upper Menka area while the cultivation of food and other cash crops are practiced within the lowland forest zones.

\subsection{Crop Cultivation Patterns in Widikum-Menka}

Typical in most rural communities in Cameroon, the indigenous people in the Widikum-Menka area largely depend on agricultural activities as a source of livelihood especially as the land has been largely devoted to crop production. Table 2 shows the various crops cultivated, hectares devoted to cultivation and output per tons for 2015 and 2016. 
Table 2. The main agricultural products in Widikum-Menka Highland, North West Region of Cameroon.

\begin{tabular}{lllll}
\hline \multirow{2}{*}{ Crop } & \multicolumn{2}{l}{ cultivated Area (ha) } & \multicolumn{2}{l}{ Output (tons) } \\
\cline { 2 - 5 } & $\mathbf{2 0 1 5}$ & $\mathbf{2 0 1 6}$ & $\mathbf{2 0 1 5}$ & $\mathbf{2 0 1 6}$ \\
\hline Maize & 75 & 80 & 15 & 16 \\
Cassava & 8 & 10 & 9.8 & 120 \\
Groundnut & 1 & 1.5 & 1 & 1 \\
Beans & 17 & 19 & 25.5 & 30 \\
Cocoa & 8.75 & 9 & 52.5 & 63 \\
Arabica coffee & 0.4 & 0.25 & 0.4 & 0.25 \\
Robusta coffee & 1 & 0.85 & 1 & 0.85 \\
Plantains & 12 & 16.5 & 300 & 495 \\
Oil palm & 2037 & 2100 & 3055 & 3244 \\
Total & 2160.15 & 2165.1 & 3460.2 & 3970.1 \\
\hline
\end{tabular}

Source; Sub-Divisional Delegation for Agriculture and Rural Development (MINADER), Widikum 2015 and 2016 Annual Report.

The soils in the Widikum-Menka area have supported the growth of a wide variety of food and cash crops (Table 2). From the statistics, it was noticed that the area devoted to agriculture increased by 4.95 hectares between 2015 and 2016. This was followed by a concomitant 509.9 tons increase in crop output. On a per crop basis, it was realized that maize registered an increase by 5 ha $(6.25 \%)$, cassava 2ha (20\%), plantain 4.5 ha $(27.3 \%)$, and the highest oil palm with 63 ha. Arabica and Robusta coffee witnessed a decrease of $-60 \%$ and $-17.6 \%$ respectively. The data also shows that the output per ton for crops like maize, cassava, beans, cocoa, plantain and oil palms increased between the period while that for coffee dropped significantly.

From field survey and focused group discussions with farmers, it was realized that the decline in yields increases with longer duration such that most farms are abandoned by the third and fourth year of cultivation. This was further proven by farmers' level of awareness on the state of land resource potentials to support agricultural production (Figure 2). This is probably due to poor and primitive land management methods.

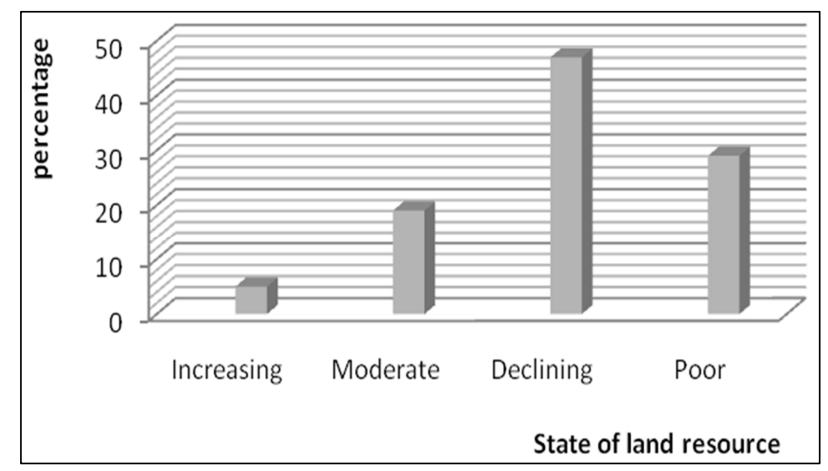

Source: Field work, (2016).

Figure 3. Indigenous appreciation on the state of land resource Potential in the Widikum-Menka.

Based on interviews and focused group discussions, it was realized that $47 \%$ of respondents stated that land resource potential to sustain food production is declining. $29 \%$ indicated that the state of their productive land is poor while $19 \%$ were for the moderate option. An insignificant proportion $(5 \%)$ of the population was for increase in land resource potential. The significance of this result is that, it supports the claim that land as a productive resource in the study area is declining. It is worthy of note that despite observed decline in the potential of the land to support agricultural production, less than $3 \%$ of farmers use fertilizers to improve on soil fertility as they remain loyal to the traditional shifting cultivation and bush fallow practices.

\subsection{Access to Agricultural Land}

Access to agricultural land in the rural milieu is a key factor to poverty alleviation and food security in the Widikum-Menka area. Statistics obtained from the field by means of interviews and focused group discussions revealed that $78 \%$ of the population has easy access to land as against $22 \%$ (mostly females) who were constrained to access good land for cultivation. Inability to access good land was observed to have two key problems on land resource potentials. It encourages the invasion and degradation of marginal lands with minimal resilience threshold to stressors. Also it leads to over cultivation of farms which accelerates fertility decline and low yields. As a consequence, yields per unit area were reported to be declining.

\subsection{Land Management Practices Adopted by the Indigenous Population}

Land management practices are key determinants of environmental sustainability which in turn affects social and economic stability of the population within and beyond their resource frontiers. From field visit to some major crop zones and pasture fields as well as discussions with farmers, it was observed that, the farming practices such as shifting cultivation, bush fallowing, intensive cultivation of marginal lands, and over grazing adopted do not guarantee ecosystems productivity/functions and soil sustainability, thus, increasing farmers' contribution to climate change in this region. Climatic caprices which are further intensified by poor land management practices within the study area represent a major threat to agricultural production as the output of most farmers now suffices just for home consumption. The following farming practices were observed to have further worsened the land degradation problems and the low outputs experienced by most farmers.

\subsection{Shifting Cultivation}

Shifting cultivation is a traditional land management practice and a characteristic of agrarian rural communities. As commonly defined, shifting cultivation depicts a situation in which a farmer moves from cultivating crops on a particular parcel of land as a result of decline in soil fertility to a virgin parcel of land as a way of boosting agricultural production. This was the case in the Widikum-Menka area before the 1970s. As a result of population increase and the introduction of the Green Revolution in the 1980s, this practice became more and more unpopular, though not completely wiped out as some evidence of shifting 
cultivation were still observed. Agricultural reforms and the Green Revolution implemented by the Cameroonian government raised the value of land to the people which fostered land consolidation for private ownership in the area. Through focus group discussions and interview with local leaders, the steady increase in the population of the area has also raised human pressure on land, necessitating effective land ownership and exploitation, thus making shifting cultivation unpopular. The act of shifting cultivation was a very unsustainable practice given that the farmer did not carter for the land, with the conception that in case of decline in output, he will move to a virgin land. Thus, the land was first being degraded by humans, and then after it was left bare, natural land degradation set in. This in turn contributed to climate change. However, if the land is not used by another individual in the near future, the soil fertility and the ecosystem functions are been restored.

\subsection{Bush Fallowing}

Bush fallowing like shifting cultivation is old age practice in the global agricultural domain. It is widely known as a situation in which with the exhaustion of the fertility of the cultivated plots, the farmers move to new sites with the intension of coming back to the same area abandoned when their fertility would have been regained. Currently, bush fallowing is the dominant farming system adopted in food crop production in the area. A set of conditions were evaluated to have necessitated bush fallowing system in the area. The fact that the soils within the area are relatively poor, given that, their natural fertility cannot sustain higher outputs over an average period of three years, fallowing becomes obvious. The high level of rural poverty in the area has hindered the ability of most farmers to afford chemical inputs and modern methods for permanent cropping. Since farmers have to depend on the natural processes for soil nourishment, bush fallowing has become a common practice. Livelihoods challenges within this highland zone have fostered large scale rural exodus over the past decades. With much land denoted to increase the land holding capacity of those left in the villages, the fallowing system is enhanced.

It is worthy of note that shifting cultivation like bush fallowing represent a cycle from land suitability to land degradation to soil replenishment back to land suitability for agricultural production. The tendency of changing farming plots within three to four years permits the farms to regain their fertility for subsequent exploitation. Furthermore, farms with fallow duration of more than fifteen years had the potential of reconstituting natural ecosystems. Such sections were noted to attract inhabitants for hunting, fuel wood harvesting, extraction of Non Timber Forest Products (NTFP's), and farming. Moreover, changing farm plots guarantees crop yields and minimizes the possibilities of household food crisis, given that their inputs in agriculture are grossly inadequate.

In spite of the stated advantages, this paper discredits the above methods adopted in land exploitation on the premise that, they do not fall in the framework of sustainable agriculture which prescribe management in all environmental components. Perhaps the contribution of these systems to high depletion of land quality is because the farmers have remained poor to modernize their farming systems and also because the landscape is too hilly/rocky such that most of the ecological niches are fragile and get critically degraded when disturbed by any stressor.

Table 2. Farming Process that Enhances Land Resource Degradation in the Area.

\begin{tabular}{ll}
\hline Processes & Resultant Effects \\
\hline \multirow{3}{*}{ Clearing } & It is the highest threat to habitat destruction, elimination of \\
& species and change in land cover. It exposes the soils to \\
& water erosion and high rate of soil moisture loss, loss of \\
& biomass and ecological disturbance. \\
& Bush burning is highly practiced and considered by the \\
& locals as the key prerequisite for higher crop yields. It \\
& ravages the biomass constituent on the farms, kills the soil \\
forming organisms, keeps the soils exposed and loose for \\
erosion and alters other soil characteristics. This diminishes \\
the potentials of the soils to sustain crop yields over longer \\
durations. \\
The method is predominated by the construction of cone- \\
shaped ridges. Such a ridge system is liable to exacerbate \\
higher rates of soil loss on the numerous steep slopes in the \\
area. Deep tillage and poor vegetation cover rapidly reduce \\
soil organic matter
\end{tabular}

Source: Field survey, 2016.

Generally, the above practices hardly support large and quality outputs worthy of transforming the livelihood of the rural farmers. This is more so as most seeds planted are of low yielding quality, little or no care accorded to the crops, inadequate inputs, poor storage facilities, and above all inadequate access to roads and poor marketing structures which makes it difficult for the rural populations to trade their products at better prices.

\subsection{Pastoral Farming}

The grazing of animals is another land use activity in the area that is predominant in the North-Eastern highlands of the Widikum-Menka area. Cattle rearing among other animals are the main form of livestock farming, a form of land exploitation which has been evaluated to have damaging effects on land resources in this region. The study observed that, the methods adopted in the grazing activity are oriented towards achieving short term pasture/cattle yields without measures for sustainable rangeland management.

Even though the size of the rangeland is relatively small (Figure 3), the area possesses some factors which have favoured the grazing of cattle. These include; the presence of high altitude pasture exploited during the wet season and low altitude pasture which sustain grazing during the dry season. Also due to its altitude $(>1000 \mathrm{~m})$, the temperature conditions are low with an annual average of $18^{\circ} \mathrm{C}$. This low temperature is a limiting factor to vectors such as tsetse fly and others which propagate animal diseases. The rangeland has a network of streams that sustain the water need of the animals. 
Despite these natural advantages, a cross-section of the grazers expressed the concern about their activity being threatened. Perhaps the opinion of Abu Nihuh of Akanunku village is most appropriate, "I am still in Akanunku because am yet to find another place. We have become many and the grass to feed our animals reduced. Either the animal is chased by a native or will slip off as we some times have to graze in difficult areas. I lose about six cattle each year and I just feel like to go". These words reflect the state of cattle production in the area. Table 3 illustrates the size of the rangelands, number of herds, and the cattle output between 2015 and 2016.

Table 3. Cattle output for selected villages in the Widikum-Menka Highland.

\begin{tabular}{|c|c|c|c|c|c|c|}
\hline \multirow{2}{*}{ Village } & \multirow{2}{*}{ Grazing land (ha) } & \multicolumn{2}{|c|}{ Number of grazers } & \multicolumn{2}{|c|}{ Number of cattle } & \multirow{2}{*}{$\%$ change } \\
\hline & & 2015 & 2016 & 2015 & 2016 & \\
\hline Akanunku & 2000 & 7 & 7 & 1031 & 870 & -18.5 \\
\hline Atong & 300 & 2 & 2 & 100 & 100 & 0 \\
\hline Baraka & 480 & 2 & 2 & 86 & 91 & 5.5 \\
\hline Anjing & 1550 & 1 & 1 & 120 & 140 & 14.3 \\
\hline Emua & 300 & 1 & 1 & 91 & 86 & -5.5 \\
\hline Ekoh & 250 & 4 & 4 & 210 & 237 & 11.4 \\
\hline Efang & 150 & 1 & 1 & 60 & 82 & 21.9 \\
\hline TOTAL & 5280 & 21 & 21 & 1914 & 1855 & -3.2 \\
\hline
\end{tabular}

Source: Widikum Veterinary and Zoo-Technical Centre, 2015 and 2016 Annual Reports.

From table 3, grazing is done in eight of the forty two villages in the Sub-Division. The total range land is 5280ha (too small relatively to the total land area for the SubDivision). The data indicates that, total cattle production witnessed a decrease of 3.2 between 2015 and 2016. The annual percentage change for each village shows a small increase except of Akanunku and Emua that registered a negative change of $18.5 \%$ and $5.5 \%$ respectively. Efang village had the highest increase $(21.9 \%)$ followed by Anjing $(14.3 \%)$ and Tanka (13.2\%) while Atong registered a zero change. Also, the decreased in the number of cattle could equally be due to the stocking rate which is too high on the rangelands as more than ten cattle are forced to feed on at most one hectare of rangeland.

\subsection{Grazing Patterns in the Area}

Pastoral nomadism is the process that describes the grazing system in the area. The system entails the daily displacement of the grazers and their animals in search of pasture and water. The study observed two types of movement; the short cycle (daily) wet season movement and the long duration (dry season) movement.

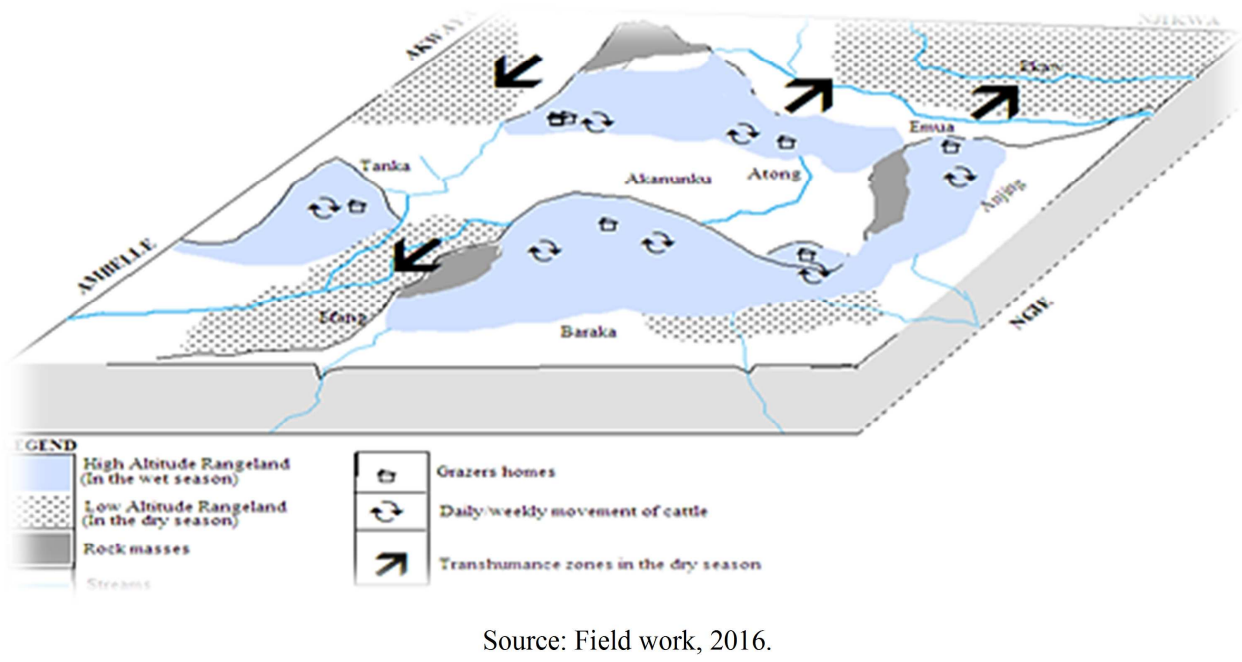

Figure 4. Grazing patterns in the rangeland in part of the Menka Highland.

As disclosed by the grazers and field observations, the hills flourish with pasture in the wet season during which grazing of animals towards the lowlands is restricted. The lowlands are noted to be inhospitable to cattle at this period due to tsetse fly infestation and other vectors that propagate animal diseases. Most of the lowlands are also cultivated at this period. Hence, between the months of May and October, there is high exploitation of the high altitude rangeland involving short distance movements within the hills (Figure 3). The dry season whose influence in the area extends between November and April introduces aridity which causes the high altitude pasture to dry up completely. This initiates long distance movements towards the low altitude rangeland with green vegetation especially along river courses. The Ekaw village and the neighboring Akwaya villages are the dense transhumance zones.

The study assessed that, the grazing system adopted do not 
ensure rangeland management. This claim was predicated on the premise that; the intensive exploitation of the high altitude rangeland for over six months showed evidence of over grazing. The burning of hills during each phase of transhumance is a limiting factor to the survival of some grasses. It also leads to general decline in pasture quality, and exposes the soils for erosion. The high concentration of cattle herds on the limited low altitude rangeland during the dry season initiates high land degradation considering that the lowlands are heavily exploited for crop cultivation as was observed in Akanuku, Tanka and Ekaw villages. Comparatively, the high altitude range showed evidence of land degradation through landslide scars, rills and gully erosion with some sections void of pasture. Low altitude rangeland on the other hand indicated the invasion of species of low pasture quality such as the bracken fern which is not a palatable specie to the animals and encroachment for crop production. With the help of different data sources, it was observed that, the rangeland is reducing in size and potential to sustain high cattle production.

\subsection{Cattle Grazing Constraints in the Area}

A range of physical and human conditions were identified as constraints to cattle raring in this area. Table 4 presents grazing constraints and relevant observations on the state of these constraints

Table 4. Grazing constraints in Widikum-Menka Highland.

\begin{tabular}{ll}
\hline Grazing constraint & Observations \\
\hline The physical landscape & $\begin{array}{l}\text { The area has numerous rock outcrops, delicate steep slopes and incised valley system which has restricted cattle } \\
\text { movement and rangeland expansion. }\end{array}$ \\
Limited pasture (quality and quantity) & $\begin{array}{l}\text { Most of the pasture along the concave foot slopes is not good for cattle. The long dry season causes the pasture to } \\
\text { be scourged and equally the invasion of the unpalatable bracken fern in the rangelands. } \\
\text { Inadequate disease control }\end{array}$ \\
Veterinary officials are not regular to treat the animals from diseases. \\
Agricultural expansion, settlement development are a threat to the grazing activity. (farmer-grazers conflict and \\
farmer-settlement conflict) \\
The grazers are deficient in capital resource to invest in ranching, pasture regeneration, research, to get the high \\
yielding and resistant species as well as to adequately treat their cattle against animal diseases.
\end{tabular}

Source: Field survey, 2016.

Over grazing on the relatively small rangeland is another main constraint. It has made the effects of trampling very pronounced on the rangeland. It has caused some sections unable to reconstitute their pasture and cause the development of erosion channels with some large enough to cause minor slope failures.

The impacts of persistent burning of hills as a strategy for the sprouting of fresh pasture are enormous on rangeland management (Ndenecho, 2010). Burning results to long term modification of pasture where undesirable plant species for the cattle often gain resilience. Such species like the bracken fern were observed to have invaded the eastern slopes of the Abakana highland between Baraka and Atong village. Prolonged burning and overgrazing on the steeper slopes with thin soils is responsible for their declining biomass productivity. Based on these, the study asserted that the status of the rangeland has changed over time as shown on Figure 4.

Figure 4 shows how the forage potential in terms of its animal unit mouths (AUMs) is reducing to keep the animal population and the range in good quality. As was disclosed, the range conditions were declining in terms of pasture quality and size representing the decreasing curve. Sod busting is fast expanding in the area as people plough up native rangeland thus destroying their ecological stability especially through the introduction of vegetation species not nutritive to the animals representing the invaders curve. This together with over grazing and bush burning has reduced the quality of the rangeland from good to fair. As the practices persist to further render the pastures poor, cattle production in this region is on a decline as observed on the increasing curve. Failure in the adoption of innovations in grazing practices most especially to address pasture development/quality, the grazing fields will further lose their potentials in sustaining cattle production in this region.

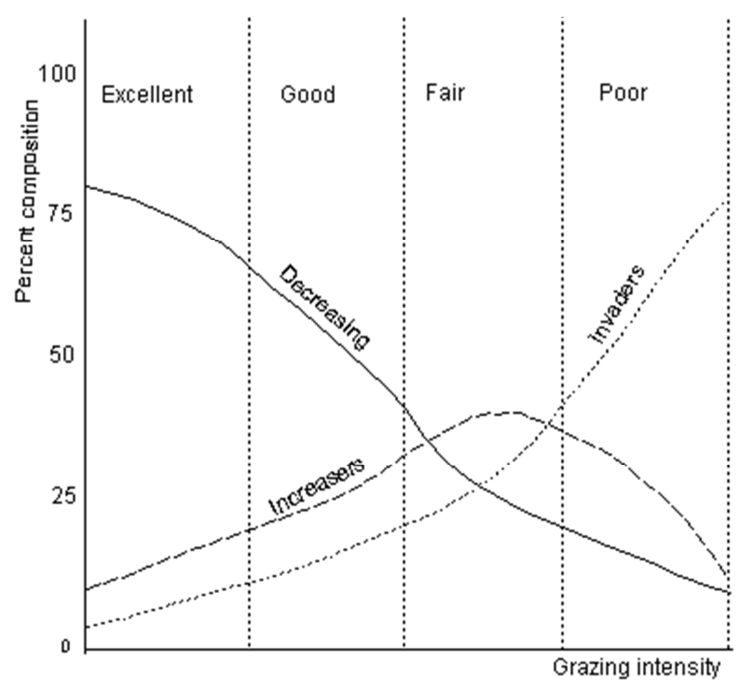

Source: Ndenecho (2005).

Figure 5. Relationship between the intensity of grazing and the relative degradation of rangeland.

\subsection{Land Exploitation Problems in Widikum-Menka Highlands}

Generally, land exploitation practices in the Sub-Division are subsistent. The agricultural sector which remains the only hope for the rural masses is challenged by a series of physical and human constraints (Table 5). 
Table 5. Agricultural land resource exploitation problems and impacts.

\begin{tabular}{|c|c|c|}
\hline Problem & Impact on resources & Observation \\
\hline $\begin{array}{l}\text { The physical } \\
\text { landscape }\end{array}$ & $\begin{array}{l}\text { Foster slope instability, soil erosion and ecosystem rehabilitation } \\
\text { difficult. }\end{array}$ & $\begin{array}{l}\text { More than } 3 / 4 \text { of the landscape is difficult for farmers to } \\
\text { efficiently exploit }\end{array}$ \\
\hline $\begin{array}{l}\text { Soil } \\
\text { infertility/erosion }\end{array}$ & $\begin{array}{l}\text { Deeply weathered laterites which are fast eroded and leached to } \\
\text { render them poor to sustain crop productivity }\end{array}$ & $\begin{array}{l}\text { A serious limitation to farmers. Without chemical inputs, } \\
\text { yields will remain low. }\end{array}$ \\
\hline Climate & $\begin{array}{l}\text { The impact of seasonality on land and water resource exploitation } \\
\text { is high. Climatic uncertainty alters the agricultural calendar. }\end{array}$ & $\begin{array}{l}\text { Agriculture is rain-fed. Low input of rain is liable for crop } \\
\text { failures in the area since irrigation schemes are absent. }\end{array}$ \\
\hline Pest and diseases & $\begin{array}{l}\text { They are crop and animal specific. Their prevalence is a huge } \\
\text { damage to crops and animals in this area. }\end{array}$ & $\begin{array}{l}\text { Pest and disease control is inadequate. Seeds, growing crops } \\
\text { and outputs are heavily damaged by pest and diseases. }\end{array}$ \\
\hline Land tenure systems & $\begin{array}{l}\text { Tenure insecurity is high to guarantee efficient management of } \\
\text { land resources. }\end{array}$ & $\begin{array}{l}\text { Ownership procedures are rigid but access to exploitation is } \\
\text { very open. Tenure insecurity encourages the unsustainable } \\
\text { use of land }\end{array}$ \\
\hline Poverty & $\begin{array}{l}\text { Foster the adoption of poor methods in the exploitation of } \\
\text { resources. Resource rehabilitation and development is poor. }\end{array}$ & $\begin{array}{l}\text { Resource exploitation methods are unsustainable. They are } \\
\text { liable to create livelihood problems and future poverty. }\end{array}$ \\
\hline $\begin{array}{l}\text { Slash and burn } \\
\text { practice }\end{array}$ & $\begin{array}{l}\text { Leads to deforestation, soil infertility, and collapse of ecosystems } \\
\text { and degradation and extinction of plant species. }\end{array}$ & $\begin{array}{l}\text { If not substituted with modern methods of cultivation } \\
\text { resource degradation will remain high in the area. }\end{array}$ \\
\hline Tilling system & Cone-shape ridges result to high soil loss on hill slops & $\begin{array}{l}\text { Contour ploughing, strip cultivation and terraces should be } \\
\text { encourage }\end{array}$ \\
\hline $\begin{array}{l}\text { Lack of stakeholder } \\
\text { support }\end{array}$ & $\begin{array}{l}\text { Innovation diffusion in sustainable exploitation and management } \\
\text { of natural resources is difficult. }\end{array}$ & $\begin{array}{l}\text { Urgent stakeholder intervention in all the resource sectors in } \\
\text { necessary. }\end{array}$ \\
\hline $\begin{array}{l}\text { inadequate farm to } \\
\text { market roads }\end{array}$ & $\begin{array}{l}\text { The economic value of resources (price) is low. Their } \\
\text { conservation as wealth is not worthwhile. }\end{array}$ & $\begin{array}{l}\text { Roads/markets infrastructural development for the area is a } \\
\text { prerequisite for poverty alleviation and development }\end{array}$ \\
\hline
\end{tabular}

Source: Field survey, 2016.

Three major problems are fast emerging in this region as a result of unsustainable land exploitation practices. These are;

Alarming rate of land degradation,

Increasing vulnerability of the population to livelihood assets and services.

Vulnerability of the population to the caprices of climate change.

Significant increase in rural exodus in search of livelihood opportunities and green havens for agriculture.

\subsection{Soil Degradation}

Soil degradation is set in motion by fragile soils and harsh climate but accentuated by land misuse, soil mismanagement, and subsistence or resource - based and low - input agriculture. The resultant effect of unsustainable agricultural practices in the Widikum-Menka highlands is land degradation. In an attempt to justify land degradation, a chemical test on soil samples collected from this region was performed. This was to ascertain the magnitude of change in soil quality over a period of thirty one years (1985 and 2016). Two sample sites were selected on the basis of their representation for the entire study area. Sample "A" illustrates the soils within Menka while sample "B", the soils within the Widikum area. To show that the soils have degraded, the present (2016) soil results has been compared with that of a base line study conducted in 1985 by MIDENO (Mission de Developpement du Nord Quest- North West Development Authority).

Table 6. Summary of soil fertility parameters for the two samples.

\begin{tabular}{|c|c|c|c|c|c|c|c|c|}
\hline \multirow{3}{*}{ Soil fertility parameters } & \multicolumn{4}{|c|}{ Sample A (Menka area) } & \multicolumn{4}{|c|}{ Sample B (Widikum area) } \\
\hline & \multicolumn{2}{|c|}{ 0-30cm (depth) } & \multicolumn{2}{|c|}{$30-60 \mathrm{~cm}$ (depth) } & \multicolumn{2}{|c|}{$0-30 \mathrm{~cm}$} & \multicolumn{2}{|c|}{$30-60 \mathrm{~cm}$} \\
\hline & 1985 & 2016 & 1985 & 2016 & 1985 & 2016 & 1985 & 2016 \\
\hline Organic carbon $\%$ & 3.81 & 2.87 & 0.99 & 0.92 & 5.02 & 2.50 & 1.22 & 1.40 \\
\hline Total Nitrogen $\%$ & 0.29 & 0.16 & 0.09 & 0.04 & 0.32 & 0.10 & 0.07 & 0.04 \\
\hline Available phosphorous & 10 & 1 & 6 & 0.5 & 8.0 & 1.0 & 1.0 & 0.00 \\
\hline $\mathrm{K}+\operatorname{cmol}(+) \mathrm{kg}$ & 0.35 & 0.21 & 0.11 & 0.09 & 0.25 & 0.21 & 0.00 & 0.00 \\
\hline $\mathrm{Ca} 2+$ & 2.04 & 1.79 & 0.01 & 0.00 & 1.90 & 1.70 & 0.53 & 0.10 \\
\hline
\end{tabular}

Source: Field study, 2016 and MIDENO, Bamenda.

General evaluation shows that, sample ' $A$ ' (Soil within Menka Area) have an average depth of $>150 \mathrm{~cm}$. They are well drained, dark reddish brown in colour. They range from clay loam to sandy clay with low overall fertility.

The general characteristics of soils in sample ' $B$ ' (soils within Widikum Area) show that, they are deep, well drained and dark brown in colour. The soils have higher clay content with moderate fertility.
The analysis was focused on evaluating the degree of change in the percentages of the different soil constituents between 1985 and 2016. It however concentrates on the general soil fertility parameters whose alterations have great implications on agricultural productivity. These soil fertility parameters include organic carbon, total nitrogen, available phosphorus and bases $(\mathrm{k}, \mathrm{mg}$ and $\mathrm{Ca})$ which are crucial in sustaining agricultural productivity. The content of these soil 
parameters was observed to differ between $0-30 \mathrm{~cm}$ and 30 $60 \mathrm{~cm}$ of soil depth. The result showed a decreasing trend in the soil fertility components in the two samples (Table 6). Based on the results on Table 6, most of the soil fertility components have decreased for the two areas from 1985 to 2016. The decrease is also significant for the top soil horizon $(0-30 \mathrm{~cm})$ than the horizon below $(30-60 \mathrm{~cm})$. The organic carbon percentage for the entire sub region decreased severely $(3.81 \%-2.875 \%)$ for the Widikum area and $5.02 \%$ $2.50 \%$ for Menka in the top horizon. This decline is probably due to farming without or with inadequate soil nourishment like organic matter, fertilizers and others. It is also because of the increasingly shorter fallow periods. This is in relation to the view of Christine Jones (1985) in Peter Donovan (2013) who noted that "the most meaningful indicator for the health of the land is whether soil is being formed or lost. If soil is being lost, so too is the economic and ecological foundation on which production and conservation are based".

The results also show that, the rate of decrease in the fertility components is higher for Menka than Widikum area. As to why this disparity should occur in soil fertility decline between the two areas, the researcher raised the following justifications;

Topographically, Menka is on a higher elevation $(>800 \mathrm{~m}$ above sea level) with a general hilly and mountainous landscape which foster higher rates of soil wash than the Widikum area with a relatively undulating landscape which is an extension of the Mamfe Basin.

Another possible justification for this disparity between the two areas is the cattle grazing activity which is restricted to Upper Menka and the excessive annual bush fires possibly account for its higher rates of land degradation.

The Widikum area is more accessible than Menka and the rest of the sub division is enclave. The accessibility of Widikum has fostered innovation diffusion and modernisation in the agricultural sector (the farmers easily access chemicals, seeds, field technicians, information) than what obtains in the rest of the subdivision.

The Widikum area has a smaller surface area (about $102 \mathrm{~km}^{2}$ ) and a higher population concentration. This was observed to have caused high population pressure on land in the Widikum area such that most farmers are forced to modernise the sector. This is not the case in the rest of the sub region hence, higher rates of land mismanagement and degradation.

\section{Conclusion}

In spite of the above spatial disparities in the rates of degradation, land resource degradation among other resources remains the major threat to rural livelihoods over the area. The rate of decrease in the parameters within the two decades is rated high according to some agrotechnicians. Despite this warning, the study disclosed that, land degradation may persist for the rest of the millennium since there exist no blue prints for sustainable agriculture and land management for the sub region. As already highlighted, rural vulnerability and population displacement to seek fertile soils elsewhere though not a recent phenomenon in the study area, the present scale of mobility is alarming. This has caused a majority of the rural poor to become "environmental refugees" as a preponderant number of them now move across regional boundaries into the Mamfe basin which hold enormous promise for agriculture (Tassah \& Lambi, 2014). However, the land resource potential for the area remains rich especially in its support of a wide range of crops. The land remains the only hope of the local masses (95\%). This hope can only be sustained when the local people, the stakeholders, the state and other organizations act promptly and objectively in addressing the problems of rural development. The adoption of sustainable land/agricultural management, land reforms and modern techniques in farming are crucial for the area.

There is need for the government and NGOs to mainstream Climate-Smart Agriculture (CSA) as a farming practice in this region. This type of agriculture is aimed at sustainably increasing agricultural productivity and income, adapting and building resilience to climate change and where possible, reducing and/or removing $\mathrm{GHG}$ emissions, relative to business-as-usual practices. Furthermore, improved and innovative farming practices like conservation agriculture, agroforestry and soil and water conservation practices besides climate smart agriculture should be introduced in this region.

\section{References}

[1] Becha N. F. (2013); Natural Resource Degradation: Management Options for Sustainable Livelihood in Widikum Sub-Division, North West Region of Cameroon. Unpublished M. Sc. Thesis. University of Buea, Cameroon.

[2] ELD Initiative (2013). The rewards of investing in sustainable land management. Interim Report for the Economics of Land Degradation Initiative: A global strategy for sustainable land management.

[3] Gabathuler E., Liniger H., Christine H., Markus G. (2009). Benefits of Sustainable Land Management. WOCAT (World Overview of Conservation Approaches and Technologies) and CDE (Centre for Development and Environment), University of Berne.

[4] Lambi C. M., Ndenecho E. N. \& Yenshu, V. (2008): Environment and Inter Community Conflicts in the North West Region of Cameroon: In Journal of Applied Social Sciences (JASS), Vol 7, No 1 (2008), Unique Printers, Bamenda.

[5] Lambi C. M (2001): Environmental Constraints and Indigenous Agricultural Intensification (Upper Nun Valley of Cameroon) in Lambi \& Eze (Ed., 2001); In Readings in Geography, Unique printers, Bamenda.

[6] Liniger, H. P., Mekdaschi. R. Studer, Hauert. C, and Gurtner M. (2011). Sustainable Land Management in Practice Guidelines and Best Practices for Sub-Saharan Africa. TerrAfrica, World Overview of Conservation Approaches and Technologies (WOCAT) and Food and Agriculture Organization of the United Nations (FAO).

[7] McCarthy, N. and Brubaker, J. 2014, Climate-Smart Agriculture and resource tenure in Sub-Saharan Africa: a conceptual framework, Rome, FAO. 
[8] Ndenecho E. Neba. (2005). Biological Resource Exploitation in Cameroon. From Crisis to Sustainable Management. Unique Printers-Bamenda.

[9] Ndenecho E. Neba. (2010). Integrating Local Livelihood Sustenance Activities in Protected Area Management: The case of Korup National Park, Cameroon. In African journal of social sciences vol 1, number 2, p 23.

[10] Peter Donovan, (2013); Measuring soil carbon change: A flexible, Practical, Local Method.

[11] Tassah I. T. (2013); Slope Dynamics and Implications on Agricultural Production in the Widikum-Menka Sub-Division, North West Region of Cameroon. Unpublished M. Sc. Thesis. University of Buea, Cameroon.
[12] Tassah I. T. \& Lambi M. C. (2014); Topographic Constraints and Agricultural Production in the Widikum-Menka Highlands, North West Region of Cameroon. In the African Journal of Social Sciences, Vol 5, No 3, November 2014. Pg 16-29.

[13] Titilola T. S. and Jeje L. K (2008). Environmental degradation and its implications for agricultural and rural development: the issue of land erosion. Journal of Sustainable Development in Africa. Volume 10 (2).

[14] UN Habitat (2010). Land, Environment and Climate Change: Challenges, Responses and Tools. United Nations Human Settlement Programme (UNHABITAT).

[15] Widikum Veterinary and Zoo-Technical Centre, 2015 and 2016 Annual Reports. 